\title{
Molten Carbonate Fuel Cell Product Design and Improvement
}

\author{
Quarterly Report \\ December 1994 - March 1995
}

August 1995

Work Performed Under Contract No.: DE-FC21-95MC30133

For

U.S. Department of Energy

Office of Fossil Energy

Morgantown Energy Technology Center

Morgantown, West Virginia

\section{By}

M-C Power Corporation

Burr Ridge, Illinois 


\section{DISCLAIMER}

This report was prepared as an account of work sponsored by an agency of the United States Government. Neither the United States Government nor any agency thereof, nor any of their employees, makes any warranty, express or implied, or assumes any legal liability or responsibility for the accuracy, completeness, or usefulness of any information, apparatus, product, or process disclosed, or represents that its use would not infringe privately owned rights. Reference herein to any specific commercial product, process, or service by trade name, trademark, manufacturer, or otherwise does not necessarily constitute or imply its endorsement, recommendation, or favoring by the United States Government or any agency thereof. The views and opinions of authors expressed herein do not necessarily state or reflect those of the United States Government or any agency thereof.

This report has been reproduced directly from the best available copy.

Available to DOE and DOE contractors from the Office of Scientific and Technical Information, 175 Oak Ridge Turnpike, Oak Ridge, TN 37831; prices available at (615) 576-8401.

Available to the public from the National Technical Information Service, U.S. Department of Commerce, 5285 Port Royal Road, Springfield, VA 22161; phone orders accepted at (703) 487-4650. 


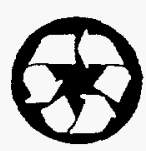

This cover stock is $30 \%$ post-consumer waste and $30 \%$ pre-consumer waste, and is recyclable. 
象

울 


\title{
Molten Carbonate Fuel Cell Product Design and Improvement
}

\author{
Quarterly Report \\ December 1994 - March 1995
}

Work Performed Under Contract No.: DE-FC21-95MC30133

For

U.S. Department of Energy

Office of Fossil Energy

Morgantown Energy Technology Center

P.O. Box 880

Morgantown, West Virginia 26507-0880

By

M-C Power Corporation

8040 South Madison Street

Burr Ridge, Illinois 60521 


\section{TABLE OF CONTENTS}

$\underline{\text { Item }}$ Page

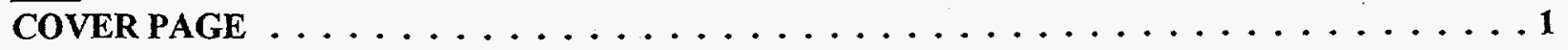

TABLE OF CONTENTS . . . . . . . . . . . . . . . . . . 2

STATEMENT OF COOPERATIVE AGREEMENT OBJECTIVES $\ldots \ldots \ldots \ldots \ldots \ldots$

SUMMARY OF WORK ACCOMPLISHED DURING THE REPORTING PERIOD BY TASK . . 5

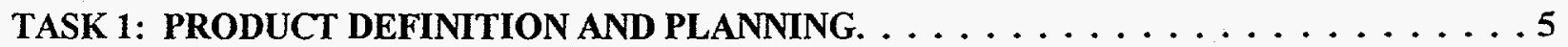

Subtask 1.1: Update Requirements . . . . . . . . . . . . . . . . . . . 5

Subtask 1.2: Update Product Definitions . . . . . . . . . . . . . . . . 5

Subtask 1.3: Update Goals . . . . . . . . . . . . . . . . . . . . 5

Subtask 1.4: Market Introduction and Manufacturing Plans . . . . . . . . . . . . . . . 5

Subtask 1.5: Task Management and Reporting . . . . . . . . . . . . . . . . . . . 6

TASK 2: SYSTEM DESIGN AND ANALYSIS $\ldots \ldots \ldots \ldots \ldots \ldots$

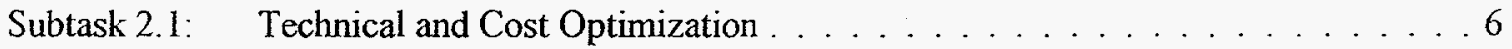

Subtask 2.2： Generate Preliminary Design . . . . . . . . . . . . . . . . . . .6

Subtask 2.3: Generate Detailed Cost Estimate . . . . . . . . . . . . . . . . . . 7

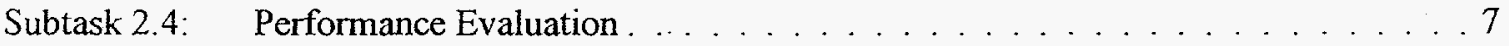

Subtask 2.5: Task Management and Reporting . . . . . . . . . . . . . . . . . . . . 7

TASK 3: MANUFACTURING PROCESS DEVELOPMENT . . . . . . . . . . . . 7

Subtask 3. 1: Optimize Active Cell Component Manufacturing Processes . . . . . . . . . . . . 7

Subtask 3.2: Cell Hardware Manufacturing. . . . . . . . . . . . . . . . . . . . . . . 8

Subtask 3.3: Develop Advanced Manufacturing Processes. . . . . . . . . . . . . . . . . 8

Subtask 3.4: Scale Up Manufacturing Process . . . . . . . . . . . . . . . . . 8

Subtask 3.5: Cost Reduction . . . . . . . . . . . . . . . . . . . . 8

Subtask 3.6: Develop and Implement QA/QC Program . . . . . . . . . . . . . . . 9

Subtask 3.7: Upgrade Analytical Capabilities . . . . . . . . . . . . . . . . . . 9

Subtask 3.8: Conceptual Power Module Factory Design . . . . . . . . . . . . . . . . . 9

Subtask 3.9: Task Management and Reporting . . . . . . . . . . . . . . . . . . . 9

TASK 4: PACKAGING AND ASSEMBLY $\ldots \ldots \ldots \ldots \ldots \ldots$

Subtask 4.1: Improve Packaging Methodology . . . . . . . . . . . . . . 9

Subtask 4.2: Verification of Packaging Methodology . . . . . . . . . . . . . 10

Subtask 4.3: Improve Assembly Methodology . . . . . . . . . . . . . . . . 10

Subtask 4.4: Verification of Assembly Methodology . . . . . . . . . . . . . . . . 10

Subtask 4.5: Design Conceptual Power Plant Assembly Factory. . . . . . . . . . . . . . . 10

Subtask 4.6: Task Management and Reporting . . . . . . . . . . . . . . . . 10

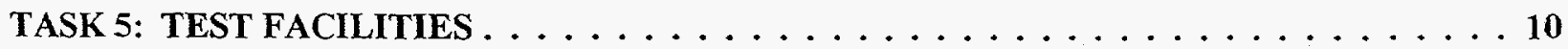

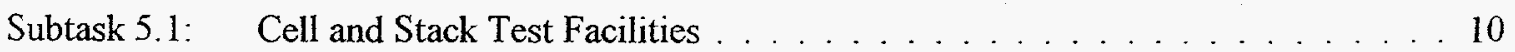

Subtask 5.2: $\quad 250 \mathrm{~kW}$ Stack Verification Facility . . . . . . . . . . . . . . . . . 11

Subtask 5.3: Power Plant Distribution . . . . . . . . . . . . . . . . . 11

Subtask 5.4: $\quad$ Task Management and Reporting . . . . . . . . . . . . . . . . . . . II 


\section{TABLE OF CONTENTS}

Item

TASK 6: TECHNOLOGY DEVELOPMENT, IMPROVEMENT AND VERIFICATION. . . . . 11

Subtask 6.1: Cell Package . . . . . . . . . . . . . . . . 11

Subtask 6.2: Fuel Cell Module . . . . . . . . . . . . . . . . . . . . 12

Subtask 6.3: Balance of Plant . . . . . . . . . . . . . . . . 12

Subtask 6.4: Full-Area Stack Testing . . . . . . . . . . . . . . 12

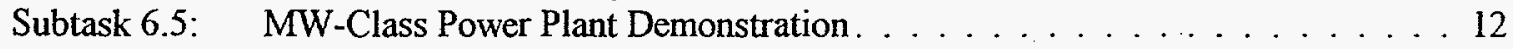

Subtask 6.6: Update Commercialization Plans . . . . . . . . . . . . . . . . . . 13

Subtask 6.7: Task Management and Reporting . . . . . . . . . . . . . . . . . . . 13

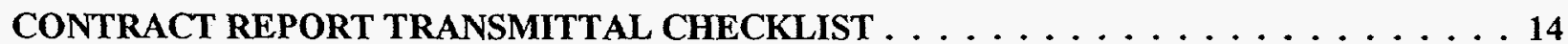




\section{Statement of Cooperative Agreement Objectives}

The primary objective of this effort is to establish, by 1998 , the commercial readiness of MW-class IMHEX ${ }^{\circledR}$ MCFC power plants for distributed generation, cogeneration, and compressor station applications. Commercial readiness will require an advanced IMHEX ${ }^{\circledast}$ technology base, lower-cost manufacturing processes, verified balance-of-plant components, proven packaging and assembly approaches, demonstrated prototype power plants, finalized manufacturing and market distribution plans and a committed commercialization team. The M-C Power Team's supporting objectives are:

- To finalize product definition, complete detailed product design, identify and evaluate balance-of-plant components, and generate power plant manufacturing and market distribution plans which will result in successful transition from development into commercial market entry;

- To develop and optimize fuel cell component manufacturing processes and power plant assembly and packaging methodologies which will provide a market-responsive MW-class power plant in low production volumes appropriate for the initial stages of commercialization;

- To advance and improve the $\mathrm{IMHEX}^{\otimes}$ stack technology, balance-of-plant components, and power plant integration which will provide the technology basis for a reliable, cost-effective MW-class product;

- To demonstrate and verify the reliability, performance, and cost-effectiveness of these technologies in a prototype IMHEX ${ }^{\circledR}$ fuel cell power plant which will establish the marketplace confidence needed for successful entry into the commercial market; and

- To establish the necessary infrastructure and strategic alliances with vendors/suppliers to support market entry and commercialization.

The work to be performed by M-C Power and the subcontractors is divided into the six tasks listed below. The objectives for each task, along with a brief update, where appropriate, is shown on the following pages, which constitutes this technical report.
Task 1:
Product Definition and Planning
Task 2:
System Design and Analysis
Task 3:
Manufacturing Process Development
Task 4:
Packaging and Assembly
Task 5:
Test Facility Development
Task 6:
Technology Development, Improvement, and Verification 
Summary of Work Accomplished During the Reporting Period By Task $\quad(12 / 19 / 94-3 / 31 / 95)$

\section{TASK 1 PRODUCT DEFINITION AND PLANNING}

The objectives of this task are to provide the product definition and plans necessary to ensure that the MW-class power plant developed and verified during this activity is responsive to the marketplace needs and conforms to M-C Power's existing Commercialization Plan and to prepare a report to satisfy the requirements of the National Environmental Policy Act.

\section{Subtask 1.1 Update Requirements}

Objective: The contractor shall update existing product requirements based on marketplace input and document the requirements of a MW-class market-responsive MCFC power plant through market surveys, product option evaluations, and analysis of applicable codes and regulations. The contractor shall prepare a market analysis report that identifies product requirements, analyzes the survey results, and identifies applicable codes and regulations.

Status: $\quad$ M-C Power is developing a preliminary market survey, which will be issued to a variety of potential customers.

Subtask 1.2 Update Product Definitions

Objective: The contractor shall generate product options based on market requirements and technical feasibility, select a market entry product approach based on its cost-effectiveness and market responsiveness, and prepare a product description document.

Status: $\quad$ No significant progress to report on this subtask during the latest reporting period.

\section{Subtask 1.3 Update Goals}

Objective: The contractor shall update and document performance, life, and cost goals for the power plant, (individual balance of plant (BOP) components, the stack module and stack components) based on the results of Tasks 1.1 and 1.2. The contractor shall utilize these detailed goals to direct and evaluate development activities and shall conduct periodic internal technical progress audits will which measure progress against the goals.

\section{Status: $\quad$ Depends on the results of subtask 1.1 and subtask 1.2.}

\section{Subtask 1.4 Market Introduction and Manufacturing Plans}

Objective: The contractor shall prepare market introduction and manufacturing plans consistent with $\mathrm{M}-\mathrm{C}$ Power's existing Commercialization Plan, the goals defined in Task 1.3, and the product definition established in Task 1.2.

The contractor shall prepare a draft report which provides the environmental information described in "Required Information for the National Environmental Policy Act (NEPA)." This information will be used by the DOE to prepare the appropriate level of NEPA documentation for the project. This draft report shall be submitted to the COR within sixty days after contract award. DOE shall review the report and advise the contractor of the acceptability of the report or the need for additional information within thirty days. The contractor shall submit a final 
report within two weeks of notice of acceptability of the draft report.

Until the NEPA review and approval process is completed and written authorization is obtained from the Contracting Officer, the contractor shall take no action that would have an adverse impact on the environment or limit the choice of reasonable alternatives to the proposed action. The contractor is not precluded from planning, developing preliminary designs, or performing other work necessary to support an application for Federal, State, or local permits.

Status: $\quad$ The required NEPA report was prepared and submitted to the Department of Energy (DOE). Initial feedback was received from the DOE that the report was acceptable $A$ market penetration plan, stack manufacturering plan, balance of plant (BOP) manufacturing plan, power plant assembly plan and power plant acceptance test plan will be developed to support this subtask.

\section{Subtask 1.5 Task Management \& Reporting}

Objective: The contractor shall issue monthly schedule and cost status reports and technical reports as well as topical and annual reports as required by the contract. Program objectives and milestones will be reviewed periodically to identify and plan corrective action for problems of a schedule or budgetary nature.

Status: $\quad$ Monthly reports have been submitted to the DOE for the PDI cooperative agreement. Also, $M-C$ Power prepares and submits a weekly report to $D$. Hooie, of the DOE, which provides additional information on the PDI project, where appropriate.

\section{TASK 2 SYSTEM DESIGN AND ANALYSIS}

The objective of this task is to conduct a system optimization study to evaluate various process options for maximizing plant performance and minimizing plant cost. Based on the selected operating parameters and plant configuration, a preliminary design and cost estimate will be prepared to analyze the overall plant performance and economics. Detailed design will be performed in subtask 6.5 .

\section{Subtask 2.1 Technical and Cost Optimization}

Objective: The contractor shall establish a baseline market-entry power plant configuration and perform a technical and cost system optimization around this baseline. The contractor shall perform trade-off studies on power plant operating conditions and scenarios. The contractor shall prepare a design document describing the baseline design and the results of the trade-off studies.

Status: $\quad$ M-C Power is developing a cost model that should provide information that will support this subtask.

\section{Subtask 2.2 Generate Preliminary Design}

Objective: $\quad$ The contractor shall generate a preliminary design of the selected market-entry power plant including process and system engineering and packaging design. The contractor shall generate process flow diagrams, piping, and instrumentation diagrams, an equipment list, and a process 
DOE Cooperative Agreement No.: DE-FC21-95MC30133

Project Start Date: 12/19/94 Project Finish Date: 12/18/99

description.
PDI 1st Quarter, 1995 Technical Report Reporting Period: $12 / 19 / 94$ to 3/31/95

Status: $\quad$ No significant progress to report on this subtask during this reporting period.

Subtask 2.3 Generate Detailed Cost Estimate

Objective: The contractor shall generate a detailed cost estimate, similar to EPRI TAG II, for the marketentry power plant including capital, installation, and operating costs and shall perform economic analyses to assess cost-effectiveness based on economic parameters such as interest rates, inflation rates, ownership criteria, and site characteristics.

Status: $\quad M-C$ Power has been developing a cost model to be used to evaluate various economic scenarios related to the market entry power plant. Cost estimates for the capital and operating costs will be developed.

Subtask 2.4 Performance Evaluation

Objective: The contractor shall conduct a performance evaluation on the market-entry power plant including design and off-design performance, dynamic simulations, and reliability, availability, maintainability, and safety (RAMS). The performance evaluation will provide complete characterization of power and heat production. Off-design performance will include analysis of part load operation. The dynamic simulations will be performed to refine control system specifications.

Status: $\quad$ No significant progress to report on this subtask during the current reporting period.

Subtask 2.5 Task Management \& Reporting

Objective: The contractor shall issue monthly schedule and cost status reports and technical reports as well as topical and annual reports as required by the contract. Program objectives and milestones will be reviewed regularly to identify and plan corrective action for problems of a schedule or budgetary nature.

Status: $\quad$ Monthly reports have been submitted to the DOE for the PDI cooperative agreement. Also, $M-C$ Power prepares and submits a weekly report to D. Hooie, of the DOE, which provides additional information on the PDI project, where appropriate.

TASK 3 MANUFACTURING PROCESS DEVELOPMENT

The objectives of this task are to reduce stack costs and improve quality by optimizing existing cell and stack manufacturing processing, assessing and implementing in-house processing of separator plates, implementing advanced, high-speed low-cost cell manufacturing processes, and to design a conceptual stack manufacturing factory.

Subtask 3.1 Optimize Active Cell Component Manufacturing Processes

Objective: The contractor shall optimize current cell and stack manufacturing processes through simulations, analyses, optimizations, automations, and process modifications and shall maintain the manufacturing equipment. The contractor shall procure install, and operate an automatic 
stacking machine for commercial-scale cells and stacks.

Status: $\quad M-C$ Power is developing a computerized process simulation that will be used to analyze the current manufacturing process as well as optimize this process. $M-C$ Power is also investigating ways to automate the current manufacturing processes in order to reduce the overall cost per $k W$ for the fuel cell stack. Also related to this subtask is the ongoing work required to maintain the existing manufacturing equipment. Major maintenance is being planned and engineered for the sintering furnace with the actual work to occur later this year.

\section{Subtask 3.2 Cell Hardware Manufacturing}

Objective: The contractor shall streamline separator plate and stack hardware manufacturing by evaluating improved plate processing techniques and by implementing advanced techniques such as improved joining, surface treating, trimming, heat treating, and other advanced techniques. The contractor shall verify promising approaches in out-of-cell and in-cell testing.

Status: $\quad M-C$ power is developing a "Mod-4" plate, which will incorporate several design improvements to the current plate design.

Subtask 3.3 Develop Advanced Manufacturing Processes

The contractor shall identify, qualify, verify, implement, and confirm advanced manufacturing processes for active components and cell/stack hardware. The advanced processes will be screened for lower-cost production through reduced scrap rates and higher throughput without sacrificing quality. The advanced processes will be verified in out-of-cell and in-cell testing.

Status: $\quad$ No significant progress to report on this subtask during this reporting period.

Subtask 3.4 Scale Up Manufacturing Process

Objective: The contractor shall scale up advanced manufacturing processes to commercial area and verify processes through manufacturing advanced components. The contractor shall procure, install, commission, and implement qualified advanced manufacturing equipment.

Status: $\quad$ No significant progress to report on this subtask during this reporting period.

\section{Subtask 3.5 Cost Reduction}

Objective: The contractor shall evaluate and implement stack cost reduction technologies including recycling of materials, recovery of processed raw materials and recycling, implementing advanced component technologies, and verifying advanced plate engineering designs and concepts.

Status: $\quad$ M-C Power is investigating several options and ideas that may lead to cost reductions in the manufacturing and assembly of the fuel cell stack. As more detailed information is available on these cost savings, they will be reported in future reports. 


\section{Subtask 3.6 Develop and Implement QA/QC Program}

The contractor shall provide an ongoing review of existing QA/QC programs and implement changes as appropriate. The contractor shall seek ISO 9001 certification.

Status: $\quad$ No significant progress to report on this subtask during this reporting period.

Subtask 3.7 Upgrade Analytical Capabilities

The contractor shall identify expanded analytical capabilities to support commercial manufacturing, QA/QC programs, manufacturing improvements, and stack testing. The contractor shall implement the required upgrades on the basis of cost/benefit analyses relative to utilizing outside services.

Status: $\quad$ No significant progress to report on this subtask during this reporting period.

Subtask 3.8 Conceptual Power Module Factory Design

The contractor shall develop a conceptual stack and power module factory design to support market-entry stack production. The conceptual design will be based on the appropriate advanced manufacturing technologies and include site and equipment layouts and staffing requirements.

Status: $\quad$ No significant progress to report on this subtask during this reporting period.

Subtask 3.9 Task Management \& Reporting

The contractor shall issue monthly schedule and cost status reports and technical reports as well as topical and annual reports as required by the contract. Program objectives and milestones will be reviewed periodically to identify and plan corrective action for problems of a schedule or budgetary nature.

Status: $\quad$ Monthly reports have been submitted to the DOE for the PDI cooperative agreement. Also, $M-C$ Power prepares and submits a weekly report to $D$. Hooie, of the DOE, which provides additional information on the PDI project, where appropriate.

\section{TASK 4 PACKAGING AND ASSEMBLY}

The objectives of this task are to improve and verify efficient and low-cost packaging and assembly methodology for the BOP and the stack module and to design a conceptual power plant factory.

Subtask 4.1 Improve Packaging Methodology

Objective: The contractor shall improve the packaging methodology for the fuel cell module and BOP equipment. The contractor shall examine mechanical and thermal integration of components. The contractor shall perform optimizations involving material and labor options.

Status: $\quad$ No significant progress to report on this subtask during this reporting period. 
Subtask 4.2 Verification of Packaging Methodology

Objective: The contractor shall verify packaging improvements from Task 4.1 using subscale models. The contractor shall perform flow simulations of manifold and piping systems to verify uniform flow distributions.

Status: $\quad$ Depends on subtask 4.1.

Subtask 4.3 Improve Assembly Methodology

Objective: The contractor shall assess the assembly of stacks, fuel cell power modules, and the balance of plant based on the packaging developed in Task 4.1. The contractor shall modify the packaging as necessary to accommodate assembly constraints.

Status: $\quad$ Depends on subtask 4.1

Subtask 4.4 Verification of Assembly Methodology

Objective: $\quad$ The contractor shall verify the power plant assembly improvements from Task 4.3 using threedimensional computer modeling. The contractor shall verify the stack assembly improvements by performing a trial assembly on the automatic stacking machine procured in Task 3.1

Status: $\quad$ Depends on subtask 4.3.

Subtask 4.5 Design Conceptual Power Plant Assembly Factory

Objective: The contractor shall design a conceptual power plant packaging and assembly plant for market entry requirements. The design will include site layout, work flow, and staffing requirements.

Status: $\quad$ No significant progress to report on this subtask during this reporting period.

Subtask 4.6 Task Management \& Reporting

Objective: The contractor shall issue monthly schedule and cost status reports and technical reports as well as topical and annual reports as required by the contract. Program objectives and milestones will be reviewed periodically to identify and plan corrective action for problems of a schedule or budgetary nature.

Status: $\quad$ Monthly reports have been submitted to the DOE for the PDI cooperative agreement. Also, $M$-C Power prepares and submits a weekly report to D. Hooie, of the DOE, which provides additional information on the PDI project, where appropriate.

\section{TASK 5 TEST FACHLITIES}

The objective of this task is to provide the facilities necessary to support cell technology and stack verification and power plant distribution. The facilities will consist of new facilities and upgraded existing facilities.

Subtask 5.1 Cell and Stack Test Facilities

Objective: The contractor shall upgrade and maintain existing bench-scale and commercial-area stack 
testing facilities and a commercial-scale stack acceptance test facility currently under construction. The contractor shall procure additional facilities including pressurized bench-scale single-cell facilities and a 50-kW pressurized stack test facility. The contractor shall maintain these facilities according to an established maintenance plan.

Status: $\quad$ No significant progress to report on this subtask during this reporting period.

\section{Subtask 5.2 250-kW Stack Verification Facility}

Objective: The contractor shall review the performance of the 250-kW MCFC power plant located at Unocal's Science and Technology Center in Brea, California and assess its operability for a second $250-\mathrm{kW}$ test. Nominal repairs will be made.

Status: $\quad$ No significant progress to report on this subtask during this reporting period.

Subtask 5.3 Power Plant Distribution

Objective: The contractor shall design, fabricate, and verify shipping fixtures for the fuel cell power module. The fixtures will protect the stack from vibration and shock damage during transportation. The contractor shall identify and secure all necessary shipping permits.

Status: $\quad$ No significant progress to report on this subtask during this reporting period.

\section{Subtask 5.4 Task Management \& Reporting}

Objective: The contractor shall issue monthly schedule and cost status reports and technical reports as well as topical and annual reports as required by the contract. Program objectives and milestones will be reviewed periodically to identify and plan corrective action for problems of a schedule or budgetary nature.

Status: $\quad$ Monthly reports have been submitted to the DOE for the PDI cooperative agreement. Also, $M-C$ Power prepares and submits a weekly report to D. Hooie, of the DOE, which provides additional information on the PDI project, where appropriate.

TASK 6 TECHNOLOGY DEVELOPMENT, IMPROVEMENT AND VERIFICATION The overall objective of this task is to provide the cell, stack, and BOP component technology developments, improvements and verifications and to provide the power plant product verification to bring a multi-fueled, integrated, simple, low-cost, modular, market-responsive IMHEX $^{\circledR}$ molten carbonate fuel cell power plant to the marketplace. This task includes design, fabrication, construction, testing, and analysis of a MW-class (nominal $1 \mathrm{MW}$ ) power plant demonstration.

\section{Subtask 6.1 Cell Package}

Objective: $\quad$ The contractor shall improve cell package cost, performance, stability, and durability using evolutionary approaches with existing technology and innovative approaches to achieve breakthroughs. Materials, geometrics, and microstructures will be addressed. Out-of-cell, single-cell, and subscale stack tests will be used to verify and implement improvements. The 
contractor shall address cathode dissolution and performance, cell sealing, thermal cycling, cell package simplification, cost reduction, and component strengthening.

Status: $\quad$ No significant progress to report on this subtask during this reporting period.

\section{Subtask 6.2 Fuel Cell Module}

Objective: The contractor shall address non-repeat stack and power module components to improve design and performance and to reduce size, weight, and cost. The contractor shall verify, implement, and confirm improvements.

\section{Status: $\quad$ No significant progress to report on this subtask during this reporting period.}

\section{Subtask 6.3 Balance of Plant}

Objective: The contractor shall identify technically critical and high-cost BOP components and equipment and shall work with suppliers to reduce cost, size, and weight and to increase reliability, performance, and durability for the market-entry product. If possible, critical or technically difficult components will be eliminated by design changes.

Status: $\quad$ No significant progress to report on this subtask during this reporting period.

\section{Subtask 6.4 Full-Area Stack Testing}

Objective: The contractor shall fabricate and operate $20-\mathrm{kW}$ atmospheric-pressure commercial-scale stacks, and 50-kW pressurized commercial-scale stacks in support of the overall technology advancement effort and MW-class power plant demonstration. The contractor shall fabricate a $250-\mathrm{kW}$ commercial-scale, commercial-height stack which can be used to verify MW-class stack technology. The contractor shall submit a test plan for each stack test for METC approval at least 30 days prior to start of the test. The contractor shall prepare a topical report on each stack test containing operating results and post-test analysis.

Status: $\quad$ No significant progress to report on this subtask during this reporting period.

\section{Subtask 6.5 MW-Class Power Plant Demonstration}

Objective: $\quad$ The contractor shall engineer and design a 1-MW nominal MCFC power plant based on the optimized system developed in Task 2. and the BOP component technology from Task 6.3. The contractor shall package and assemble the power plant based on the methodology resulting from Task 4 . The contractor shall incorporate the advanced IMHEX ${ }^{\circledR}$ stack and power module technology resulting form Tasks 6.1 and 6.2 and the optimized manufacturing processes from Tasks 3.1 and 3.2 into the power module design. The contractor shall establish power plant operational goals and a test plan based on operating experience form the Unocal and SDG\&E power plant tests and the stacks tests conducted under Task 6.4. The contractor shall submit the test plan to the DOE COR for approval at least 30 days prior to the scheduled start of the demonstration. The contractor shall operate the power plant according to the approved test plan for approximately six months. The contractor shall prepare a Topical Report describing operating experience. Additional activities associated with the completion of this subtask are listed below. 

6.5.1 Site Selection and Permitting
6.5.2 Power Plant Design
6.5.3 Power Module Design, Fabrication, \& Commissioning
6.5.4 Power Plant Construction
6.5.5 Power Plant Verification

Status: $\quad$ No significant progress to report on this subtask during this reporting period.

\section{Subtask 6.6 Update Commercialization Plans}

Objective: The contractor shall update the Commercialization Plan, the market-entry power plant definition, and the Market Introduction and Manufacturing Plans (Task 1.4) based on the results of and experience gained from the 1-MW power plant demonstration.

Status: $\quad$ No significant progress to report on this subtask during this reporting period.

Subtask 6.7 Task Management \& Reporting

Objective: The contractor shall issue monthly schedule and cost status reports and technical reports as well as topical and annual reports as required by the contract. Program objectives and milestones will be reviewed periodically to identify and plan corrective action for problems of a schedule or budgetary nature.

Status: $\quad$ Monthly reports have been submitted to the DOE for the PDI cooperative agreement. Also, $M-C$ Power prepares and submits a weekly report to $D$. Hooie, of the DOE, which provides additional information on the PDI project, where appropriate.

Description of Attachments

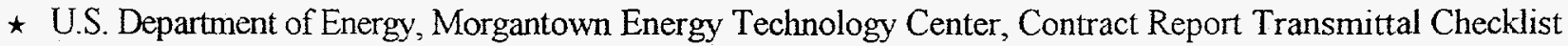

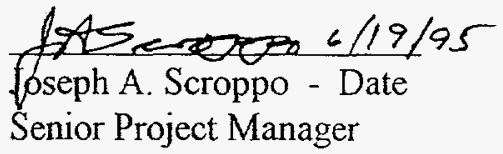

DOE Reviewing Representative 